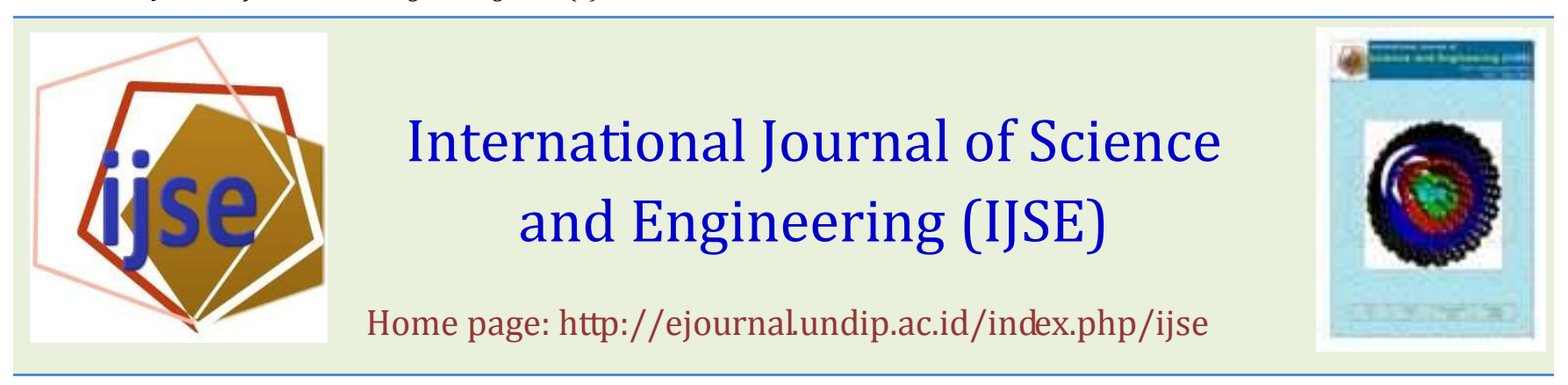

\title{
Potential Development of Liquid Smoke from Oil Palm Solid Waste as Biofungicides
}

\author{
Asri Gani *, Husni †, Akhmad Baihaqi††, M.Faisal*) \\ *Department of Chemical Engineering, Syiah Kuala University, Aceh, INDONESIA \\ †Department of Agro technology, Syiah Kuala University, Aceh, INDONESIA \\ ††Department of Agribusiness, Syiah Kuala University, Aceh, INDONESIA \\ *Department of Chemical Engineering, Syiah Kuala University, Aceh, INDONESIA
}

Tel : +62-651-7412301, Fax: +62-651-52222, email : asri.gani@che.unsyiah.ac.id

\begin{abstract}
This research investigated the potential utilization of solid waste from palm oil industry for liquid smoke production in Aceh Province, Indonesia. The liquid smoke can be applied as bio fungicides in agricultural field. Preliminary experiment on the use of liquid smoke as fungicide at Colletotrichum capsisi fungus which causes anthracnose disease on red pepper was also conducted. The survey on the existing potential/availability of palm oil mill in Aceh shows that there are 30 palm oil mills in eight districts with a total of production capacity 1020 ton/hour. Assuming that $10 \%$ of palm oil kernel shells are pyrolized into liquid smoke, Aceh province could produce about 23,868 ton of liquid smoke per year. The preliminary test result towards Colletotrichum capsisi fungus shows that the liquid smoke can be used as fungicides.
\end{abstract}

Keywords: Potential, Liquid Smoke, Biofungicides, Palm Kernel Shell, Pyrolysis, Colletotrichum Capsisi

Doi: Doi: $10.12777 /$ ijse.7.1.65-69

[How to cite this article: Gani, A.., Husni, Baihaqi, A., Faisal, M. 2014. Potential Development of Liquid Smoke from Oil Palm Solid Waste as Biofungicides. Internat. J. Sci. Eng, 7(1):65-69; Doi: 10.12777/ijse.7.1.65-69]

\section{Introduction}

Indonesia is one of the agricultural countries with abundant natural resources. A large amount of biomass waste is generated from agriculture and plantations sector. The increase of agricultural products will also increase the waste proportionally. Unfortunately, the potential of various agricultural biomass wastes has not been optimally developed. One of Indonesia's largest industries is oil palm that generates a large quantity of residues and wastes in the form of empty fruit bunch, palm kernel shells, fibre, trunk of the plant, and leaves. This biomasses waste is generally burned directly in situ for heating purposes in the factory. The waste could actually be used for the production of value added chemicals with the corresponding processes such as pyrolysis. Only about $40 \%$ of the shells have been used for energy source1-4, while the trunk and palm empty fruit bunches are usually spread in the plantation area, thereby increasing the amount of greenhouse gas emissions. One of the methods to utilize the potential of Indonesia's palm oil waste is by pyrolysis to produce liquid smoke which can be used as a bio-agent againts plant disease. Liquid smoke is a product obtained from condensation of pyrolized biomass containing several compounds that function as an antibacterial, anti-fungal and antioxidant so it can be a natural substance to overcome pest and disease problems. The use of liquid smoke in agricultural sector will support the "go organic" program in order to develop security and independent programs in agriculture. Thus, the using of waste biomass from the palm oil industry as a natural pesticide will support development of sustainable agricultural products. To our knowledge, an intensive research on the effectiveness of various smoke liquid biomass waste as a natural pesticide has not been conducted. A new innovation to produce appropriate liquid smoke for bio-pesticides is required.

The use of organic materials from waste and agricultural by-products to produce liquid smoke also 
results in an increase of economic and social value added. Pest control by organic method can maintain the balance of ecosystems and impacts on health and quality of agricultural products. In addition, a byproduct of liquid smoke can also be used as a fertilizer as well as a good source of carbon.

The objective of this research is to study the potential development of liquid smoke industrial in Aceh province as a natural agent to overcome the various problems in agriculture, especially in the case of the use of synthetic pesticides. In addition, a preliminary result of liquid smoke ability on fungus that commonly grows on red pepper is also discussed. The ability of liquid smoke as a natural fungicide is tested on colletotrichum capsici causing anthracnose disease on red pepper.

\section{Experimental}

\section{Survey of Liquid Smoke Potential}

Data of potential development of liquid smoke from solid waste of oil palm was collected by direct survey to several oil palm factories in Aceh Province. The amount of palm biomass wastes (i.e. shells) as potential raw material of liquid smoke production was investigated and tabulated. In addition, some data from statistical office board of Indonesia were also used.

Preparation of Liquid Smoke

A pyrolysis reactor with a capacity of $10 \mathrm{~kg} /$ day was designed using stainless steel material in order to keep the liquid smoke product free from heavy metal contents. The reactor setup mainly consists of a fixed-bed reactor, an outside heater, tar trap, a cooler, and connecting pipe lines. Figure 1 showed the schematic diagram of liquid smoke production process. The reactor was equipped with temperature control which can be operated until $500^{\circ} \mathrm{C}$. Sample of palm kernel shell was obtained from PT. Fajar Baizury, a local palm oil mill in Nagan Raya, Aceh.

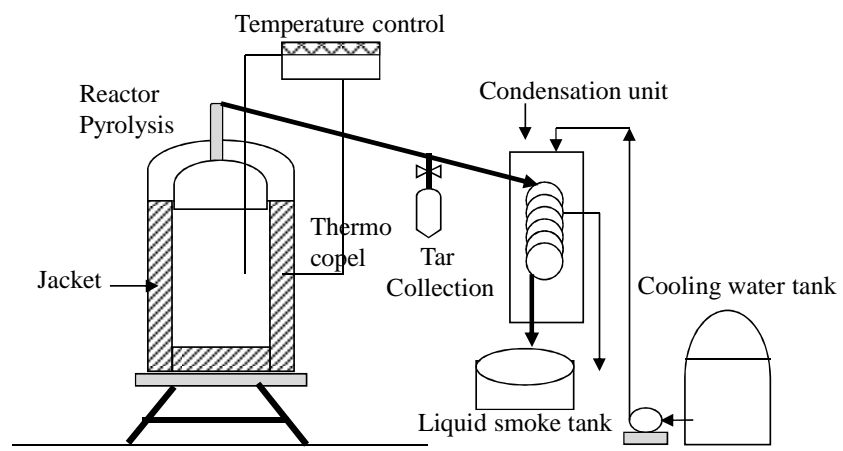

Fig. 1. Schematic diagram of experimental apparatus.

The samples were dried under the sun for 1 day prior to pyrolysis experiment. For each type of pyrolisis experiment, the sample was loaded into the reactor. The reactor was then sealed and the sample was heated externally from ambient temperature to the required operating temperature. The temperature varied from 300 to $400^{\circ} \mathrm{C}$. Discharged smoke was then condensed in a condensation unit (made of stainless steel material) in order to liquefy the smoke. The liquid smoke obtained after this condensation was liquid smoke grade 3 . The process was optimized to obtain the high yield of liquid smoke product. The chemical components in liquid smoke were identified using GC-MS 2010 (Shimadzu).

The liquid smoke ability as natural fungicide was tested on Colletotrichum capsici cause of anthracnose disease in a red pepper. Liquid smoke concentration was varied from 1 to $5 \%$. Pathogen inoculation was conducted by dying the pepper into suspension of C. capsici by density 106 conidia/ml until wet. Parameters controlled were: incubation period, number of spotted and size spotted.

\section{Results and Discussion \\ Potential Utilization of Biomass Waste from Oil Palm to Produce Liquid Smoke}

The development of pyrolysis reactor batch-based to produce liquid smoke from coconut shell for using as rubber clot substance has been done in Aceh Province before. A liquid smoke industry based on coconut shell with a capacity of $1200 \mathrm{~kg} / \mathrm{batch}$ was already established with funding support from the World Bank (Multi Donor Fund) in Beunyot Village, Regency of Bireuen in 2011 (Machdar et al, 2011). The liquid smoke produced from this industry is widely used for clotting material in rubber processing. Nevertheless, the use of coconut shell to produce liquid smoke will face a lack of raw material problem. Coconut shell is normally used as ornamental and souvenir materials which have higher sale value than that of a raw material for liquid smoke. Several liquid smoke factories that use coconut shell as raw material have stopped producing due to lack of the raw material. Thus, it is necessary to seek other alternative raw material. The use of biomass waste from the oil palm industry offers the solution for the shortage of raw materials. The survey towards palm oil factories identified a number of 30 palm oil mills in Aceh. The factories are located in eight regencies with an operating capacity of 1020 tons/hours. Generally, the palm oil mill operated \pm 20 hours/day, sometime if raw material of fresh fruit bunches (FFB) is overabundance, the factory may operate 24 hours/day. The palm oil mill produced extremely great quantity of solid wastes out of the total raw material intake, i.e: empty fruit bunches (21-23\%), oil palm shell (5-7\%), fibrous (12-15\%), bough, stem and leaves (Mahidin and Faisal, M., 2013; Chuah et al,. 2006; Yusof, B., 2006). Those wastes should be utilized properly, or they will harm the environment. The oil palm shell, for example, can be utilized for recovery of useful chemical (Na-Ranong, D. et al., 2008), activated carbon (Guo J et al., 2008; Tan W et al., 2012) aggregate in concrete (Alengaram et al, 2013) and hydrogen production (Ahmed Y., et al, 2013). Figure 2 shows the distribution of solid waste produced in oil palm processing industry. Table 1 shows the quantity of biomass waste produced by oil palm sector in Aceh in 2013. The biomass quantity was calculated based on production capacity of oil palm mill, where the mill has a production time of 20 hours a day and 300 days in a year. 


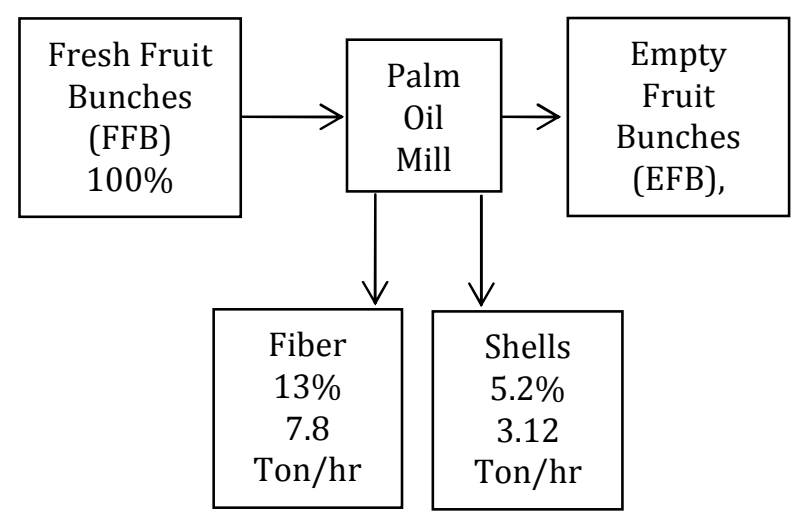

Fig. 2. Distribution of solid wastes in oil palm processing industry (Capacity: $60 \mathrm{Ton} / \mathrm{hr}$ ).

The calculation was also based on factory operation by average capacity of $75 \%$. Table 2 shows the amount of oil palm shell potential which may be utilized as raw material of liquid smoke production. The highest number of palm oil mill in Aceh is located in Tamiang district. There are 10 factories with a total capacity of 2,190,000 ton/year. The liquid smoke potential obtained from an assumption that $10 \%$ of shell waste will be used as raw material of oil palm. This assumption was based on a field survey, that approximately $60 \%$ of shell waste has been used as fuel for boiler (Machdar et al, 2013; Gani, A., et al., 2013). Based on such assumption, the potential of liquid smoke available in Aceh Province could achieve 23,868 tons/year.

Development of oil palm plantation in Indonesia is increasing rapidly. This can be seen from total acreage of oil palm plantation which continues to increase to 7.9 million hectares in 2011. Therefore, oil palm shell availability for the raw material of liquid smoke is very promising.
Table 1. Solid biomass from oil palm industries of Aceh Province in 2013.

\begin{tabular}{lccc}
\hline Biomass & $\begin{array}{c}\text { Amount } \\
\text { (ton) }\end{array}$ & $\begin{array}{c}* \text { Moisture } \\
\text { content }(\%)\end{array}$ & $\begin{array}{c}* \text { Oil content } \\
\text { (remaining) } \\
(\%)\end{array}$ \\
\hline $\begin{array}{l}\text { Empty } \\
\text { fruit }\end{array}$ & $1,009,800$ & 62 & 5 \\
$\begin{array}{l}\text { bunches } \\
\text { Fibre }\end{array}$ & 596,700 & 45 & \\
Shells & 238,680 & 7 & 5 \\
\hline
\end{tabular}

Note: ${ }^{*}$ adopted from ref. 7 and 8.

\section{Composition of chemicals in Liquid smoke from oil palm shells}

Table 3 shows the chemical contents of liquid smoke from pyrolysis of oil palm shell. There are about 20 chemical compounds detected by Gas Chromatography Mass Spectometry (GCMS). Phenolic compound may be responsible for the biofungicides against diseases in plant. Several researches have reported the mutagenic potential of chemical compound of liquid smoke of pyrolysis result. Chemical compound in wood smoke extraction may have mutagenical impact in lymph gland of human being, but has no mutagenic potential in examination using the bacterial. (Putnam et al, 1999) reported that wood smoke was mutagenically on Salmonella. The mutagenic potential of chemical compound result of pyrolysis is very influenced by the matter or type of wood used and method used to earn such chemical compound. Although mutagenic potential of wood smoke has been reported, but no study has been conducted about toxicity of liquid smoke, particularly the liquid smoke originated from result of coconut shell pyrolysis.

Tabel 2. Potency of Liquid smoke production in Aceh province.

\begin{tabular}{|c|c|c|c|c|c|c|c|}
\hline No & District /City & $\begin{array}{c}\text { Number } \\
\text { of oil } \\
\text { palm } \\
\text { mill }\end{array}$ & $\begin{array}{l}\text { Capacity } \\
\text { (ton/hr) }\end{array}$ & $\begin{array}{l}\text { Capacity } \\
\text { (ton/ Year) }\end{array}$ & $\begin{array}{l}\text { Operation } \\
\text { capacity } \\
\text { (ton/year) }\end{array}$ & $\begin{array}{c}\text { Shells } \\
\text { produced } \\
\text { (ton/year) }\end{array}$ & $\begin{array}{l}\text { Liquid smoke } \\
\text { potency* } \\
\text { (ton/year) }\end{array}$ \\
\hline 1 & Bireuen & 2 & 50 & 300,000 & 225,000 & 11,700 & 1,170 \\
\hline 2 & Aceh Utara & 1 & 60 & 360,000 & 270,000 & 14,040 & 1,404 \\
\hline 3 & Aceh Timur & 3 & 90 & 540,000 & 405,000 & 21,060 & 2,106 \\
\hline 4 & Aceh Tamiang & 10 & 365 & $2,190,000$ & $1.642,500$ & 85,410 & 8,541 \\
\hline 5 & Aceh Jaya & 1 & 30 & 180,000 & 135,000 & 7,020 & 702 \\
\hline 6 & Aceh Barat & 2 & 60 & 360,000 & 270,000 & 14,040 & 1.404 \\
\hline 7 & Nagan Raya & 4 & 150 & 900,000 & 675,000 & 35,100 & 3,510 \\
\hline \multirow[t]{2}{*}{8} & Aceh Singkil & 7 & 215 & $1,290,000$ & 967,500 & 50,310 & 5,031 \\
\hline & Total & 30 & 1,020 & $6,120,000$ & $4,590,000$ & 238,680 & 23,868 \\
\hline
\end{tabular}

* assume: $10 \%$ of Shells are utilized for liquid smoke 
Table 3. Composition of liquid smoke produced from pyrolysis of oil palm shells

\begin{tabular}{cclc}
\hline $\begin{array}{c}\text { Peak } \\
\text { Number }\end{array}$ & $\begin{array}{c}\text { Retention } \\
\text { Time (min) }\end{array}$ & \multicolumn{1}{c}{ Compounds } & $\begin{array}{c}\text { Concentration } \\
(\%)\end{array}$ \\
\hline 1 & 3.528 & Carbamic acid, monoammonium salt (CAS) Ammonium carbamate & 5.66 \\
2 & 11.974 & Benzenesulfonic acid, 4-hydroxy- (CAS) Benzenesulfonic acid, p-hydroxy- & 18.13 \\
3 & 12.175 & Phenol (CAS) Izal & 7.54 \\
4 & 12.250 & Phenol & 6.96 \\
5 & 12.338 & Benzenesulfonic acid, 4-hydroxy- (CAS) Benzenesulfonic acid, p-hydroxy- & 19.27 \\
6 & 12.708 & Phenol, 2-methyl- (CAS) o-Cresol & 3.06 \\
7 & 12.817 & 2H-Pyran-2-one, tetrahydro- (CAS) 5-Valerolactone & 3.03 \\
8 & 12.962 & Phenol, 4-methoxy- (CAS) Hqmme & 4.81 \\
9 & 13.100 & Butanoic acid, 2-propenyl ester (CAS) Allyl N-Butanoate & 8.23 \\
10 & 13.562 & Phenol, 2,3-dimethyl- (CAS) 2,3-Dimethylphenol & 2.09 \\
11 & 13.750 & Phenol, 3-ethyl- (CAS) m-Ethylphenol & 1.01 \\
12 & 13.854 & 2-Methoxy-4-methylphenol & 2.68 \\
13 & 16.282 & 1,6-Anhydro-Beta-D Glucopyranose (Levoglucosan) & 7.51 \\
14 & 17.089 & Desulphosinigrin & 3.26 \\
15 & 17.317 & 1,4-Butanediol, diacetate (CAS) 1,4-Diacetoxybutane & 2.45 \\
16 & 17.753 & Ethylpropyl & 0.78 \\
17 & 18.277 & Hexadecanoic acid (CAS) Palmitic acid & 0.99 \\
18 & 19.331 & 9-Hexadecenoic acid (CAS) & 0.77 \\
19 & 19.428 & Octadecanoic acid (CAS) Stearic acid & 0.87 \\
\hline & 22.848 & 1,2-Benzenedicarboxylic acid, dioctyl ester (CAS) Dioctyl phthalate & 0.92 \\
\hline
\end{tabular}

This research on toxicity of liquid smoke is very important considering that currently it has been widely used commercially by food industry (Guillen MD, 1999; Soldera S., et al, 2008). Various chemical components in liquid smoke can play a role as antioxidant and antimicrobial and give a color effect and specific taste of smoke to food product (Tan et al, 2008). Based on the character of several liquid smoke components, the compounds in liquid smoke could act as natural insecticide and pesticide in agriculture sector. However, the use of liquid smoke in industry is not optimized due to a lack of security standard.

Biomass waste from various agricultural products has specific chemical and physics properties which will produce the different liquid smoke quality as well. Therefore, investigation and analyses of liquid smoke components in various biomass wastes is crucial prior to its application.

\section{Preliminary Results of Liquid Smoke as Natural Fungicide}

Liquid smoke contains oxidized organic compound, such as ketone, aldehyde, phenol, and carboxylate acids group which were obtained from steam condensation result of pyrolysis (combustion non-oxygen) plant and wood processing at $400 \mathrm{oC}$ (Soldera et al., 2008). According to Pranata, 2009, oil palm shell contains lignin (29.4\%), hemicellulose $(27.7 \%)$, cellulose $(26.6 \%)$, water $(8.0 \%)$, extractive component (4.2\%), and ashes (0.6\%).

Isolation of Pathogen: Pathogen was obtained from red pepper having a disease in the field. Afterwards, fungus colletotrichum capsici in the plant part was isolated from the fruit showing rotten fruit symptom.

The treatment of preliminary test on $c$. capsici was conducted in liquid smoke concentration of $1-50 \%$.

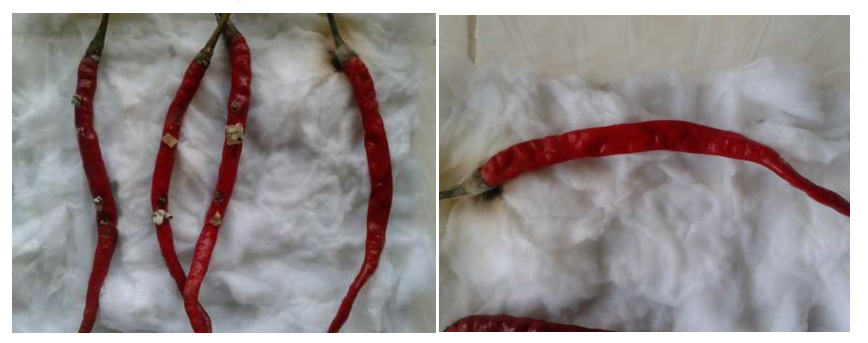

Fig. 3. Preliminary test for the ability of liquid smoke as biofungicides againts $C$. Capsici at red pepper. (Liquid smoke concentration of 5\%).

The result showed that all fruit inoculated by fungus $C$. capsici showed infection symptom even after treatment with liquid smoke. The use of liquid smoke with too high concentration resulted in damaged of the pepper, probaly because high liquid smoke contents broke the resistance 
of pepper so that it become more susceptible to the disease. In the treatment of liquid smoke with concentration varied from 10 to 25 , the average spotted diameter of infection formed was $4.2 \mathrm{~mm}$. The result indicated that the smallest infection was obtained for treatment of liquid smoke with concentration of $5 \%$. The liquid smoke of palm shell was anti-microbial due to the high contents of phenol and acetic acid which can hinder $C$. capsici growth. The complete result of preliminary test using $5 \%$ liquid smoke as biofungicides againts $C$. capsici at red chili is shown in Figure 3.

\section{Conclusions}

Oil palm processing industries generate solid waste that can be utilized to support the sustainable development of agriculture sector. There is a great potency for the production of liquid smoke from pyrolysis of Oil palm shell in Aceh province. This province can produce up to 23,868 tons of liquid smoke from Oil palm shell waste per year. Preliminary test on the ability of liquid smoke oil palm shell pyrolysis as fungicide and pesticide indicated that liquid smoke at concentrations of $5 \%$ or less may inhibit the growth of fungus $C$. capsici causing anthracnose disease in red pepper. The results also indicated that giving the liquid smoke with high concentration can cause significant damage to the pepper.

\section{Acknowledgements}

The authors gratefully acknowledge the financial support by Directorate General Higher Education of Indonesia for Research Grant of The Masterplan for Acceleration and Expansion of Indonesia's Economic Development (MP3EI) Grant no. 303/SP2H/PL/DIT.LITABMAS/VII/2013.

\section{References}

1. Ahmed Y, Ahmad MM, Lam HL, Yusup S. Clean Techno Environl Policy 2013; 15:513-523.

2. Alengaram UJ, Al Muhit BA, Jumaat MZ. Constr Build Mat 2013; 38:161-172.

3. Chuah TG, Wan Azlina AGK, Robiah Y, Omar R. Int J Green Energy 2006; 323-346.

4. Faisal M, Mahidin, Inter J on Adv Sci Eng Inform Technol 2013; 3(3): 32-38.

5. Faisal, M, Machdar I., Fatanah, U., Amhar AB, Ernawati, Technical report, DP2M, DGHE, 2012.

6. Gani A, Husni, Baihaqi A, Faisal M. The 7th International Conference of Chemical Engineering on Science and Applications, 18-19 September 2013, Banda Aceh, Indonesia,pp.399.

7. Guillen MD, Ibargoitia ML. J Agric Food Chem 1999; 47: 4126-4136.

8. Guillen MD Ibargoitia ML. J. Agric Food Chem 1998; 46: 1276-1285.

9. Guo J, Gui B, Xiang S, Bao X, Zhang H, Lua, AC. J Porous Material 2008; 15: 535-540.

10. Machdar I., Fatanah, U., dan Faisal, M. MDF-World Bank. http://www.aceh-edff.org/2011.

11. Mahidin, Faisal M. J Energ \& Environ 2013; 38-42.

12. Mahidin, Machdar I, Faisal M, Nizar M. Makara J Technol 2013; 16(2): 192-200.

13. Na-Ranong D, Yuangsawad R, Tago T, Masuda T. Korean J Chem Eng 2008; 25(3) : 426-430.

14. Prananta J. http://www.scribdcom/doc/4142857, retrieved on 26 Februari 2009.

15. Putnam KP, Bombick DW, Avalos JT, Doolittle DJ. Food Chem Toxicol 1999; 37: 1113-1118.

16. Soldera S, Sebastianut N, Bortolomeazzi R. J Agric Food Chem 2008; 56: 2727-2734.

17. Tan W, Othman R, Matsumoto A, Yeoh F. J Ther Anal Calorim 2012; 108:1025-1031.

18. Yusof B. Symposium on sustainable resources development, 18 May 2006, London. 